\title{
PENGAYAAN MATERI PERTUMBUHAN DAN PERKEMBANGAN TUMBUHAN MELALUI PENGEMBANGAN BAHAN AJAR
}

\author{
Supriyatin \\ Pendidikan Biologi, FMIPA, Universitas Negeri Jakarta \\ Jalan Rawamangun Muka, Jakarta Timur \\ Email: titin7765@gmail.com \\ Ilmi Zajuli Ichsan \\ Pendidikan Biologi, FMIPA, Universitas Negeri Jakarta \\ Jalan Rawamangun Muka, Jakarta Timur \\ Email: ilmizajuli95@gmail.com
}

\begin{abstract}
Abstrak
Pengembangan berbagai perangkat pembelajaran memunculkan inovasi yang baru dalam pembelajaran biologi. Salah satu perangkat yang dapat dikembangkan adalah bahan ajar. Bahan ajar yang digunakan di sekolah masih sangat konvensional dan belum memiliki informasi mendalam bagi siswa di luar materi dasar. Hal ini membuat pembelajaran di sekolah belum bisa maksimal. Tujuan dari penelitian ini adalah untuk mengembangkan buku pengayaan pada materi pertumbuhan dan perkembangan tumbuhan bagi siswa SMA. Metode penelitian yang digunakan adalah research and development model pengembangan Borg \& Gall. Hasilnya menunjukan bahwa buku pengayaan hasil pengembangan valid dan layak digunakan sebagai bahan ajar biologi untuk siswa dengan nilai rata-rata 3,63. Hal ini dikarenakan buku pengayaan ini memiliki banyak keunggulan yaitu mengandung materi yang lebih mendalam dan detail untuk merangsang daya analisis siswa. Kesimpulannya adalah buku pengayaan hasil pengembangan layak digunakan untuk pembelajaran.
\end{abstract}

Kata Kunci: Buku Pengayaan, Bahan Ajar, Pertumbuhan dan Perkembangan Tumbuhan.

\begin{abstract}
Development of various learning tools will bring new innovation in biology learning. One of the devices that can be developed is teaching material. Teaching materials used in schools are still very conventional. This makes learning at school not yet maximal. The purpose of this study was to develop an enrichment book on the material of plant growth and development for high school students. The research method used is the research and development model development of Borg \& Gall. The results show that the enrichment books developed are valid and appropriate to be used as Biology teaching materials for students with average score 3.63. This is because this enrichment book has many advantages which are essentially to stimulate the power of student analysis. The conclusion is that the enrichment book of the development results is appropriate for learning.
\end{abstract}

Keywords: Enrichment Books, Teaching Materials, Plant Growth and Development 


\section{PENDAHULUAN}

Mata pelajaran biologi merupakan salah satu mata pelajaran yang cukup menjadi perhatian. Mata pelajaran biologi di sekolah memiliki banyak kendala, salah satunya dalam hal hasil belajar siswa rendah. Hal ini dibuktikan dengan hasil penelitian tentang upaya meningkatkan hasil belajar biologi siswa di berbagai jenjang (Black, Bauer, Spano, Voelkel, \& Palombaro, 2017; Ichsan, Sigit, \& Miarsyah, 2018; Srisumra, Nontamolee, \& Srijamon, 2014). Hasil belajar biologi khususnya pada ranah kognitif merupakan salah satu komponen penting yang menjadi sorotan. Hal ini dikarenakan mata pelajaran biologi merupakan salah satu mata pelajaran yang termasuk dalam mata pelajaran yang ada di ujian nasional.

Hasil penelitian menunjukkan bahwa dengan inovasi bahan ajar yang baru dapat meningkatkan hasil belajar biologi. Bahan ajar yang digunakan di sekolah masih sangat konvensional dan masih sedikit yang dikembangkan. Hal ini membuat pembelajaran di sekolah belum bisa maksimal. Penelitian menunjukan bahwa hasil belajar sangat bergantung kepada perangkat pembelajaran yang disiapkan oleh guru, salah satunya bahan ajar yang disiapkan sesuai dengan materi yang akan diajarkan (van der Veen \& van Oers, 2017).

Pengembangan bahan ajar merupakan salah satu komponen penting dalam pembelajaran. Pengembangan bahan ajar yang sudah dilakukan validasi oleh ahli dan sudah teruji efektivitasnya membuat hasil belajar kognitif siswa meningkat dan juga membuat siswa menjadi lebih aktif. Hal ini dikarenakan siswa tertarik dalam pembelajaran yang menggunakan bahan ajar yang dikembangkan dan belum pernah ada sebelumnya di sekolah (Ichsan, Dewi, Hermawati, \& Iriani, 2018; Ito \& Kawazoe, 2015; Seechaliao, 2017; Uzun, 2012).

Hasil observasi yang telah dilakukan menunjukan bahwa masih banyak guru yang hanya menggunakan bahan ajar konvensional untuk seluruh materi biologi di SMA (Ichsan, Dewi, et al., 2018). Hal ini membuat pembelajaran biologi di jenjang SMA belum bisa maksimal. Salah satu materi yang menjadi kesulitan terbesar guru dalam menyampaikan materi adalah materi pertumbuhan dan perkembangan tumbuhan. Berdasarkan hasil pengamatan, materi pertumbuhan dan perkembangan pada tumbuhan menjadi salah satu materi dengan hasil belajar siswa yang masih rendah. Hal ini dikarenakan guru hanya terpaku pada materi yang ada di text book, padahal masih 
banyak sekali contoh-contoh pertumbuhan dan perkembangan tumbuhan yang ada di kehidupan sehari-hari dan lebih mendalam. Bahan ajar yang digunakan oleh guru biasanya belum terlalu mendalam didasarkan pada observasi yang telah dilakukan. Hal ini diperlukan sebuah pengembangan bahan ajar yang bersifat pengayaan, sehingga materi yang disajikan menjadi lebih expert dan lebih mendalam. Tujuannya agar pengetahuan peserta didik menjadi lebih mendalam.

Tujuan dari penelitian ini adalah untuk mengembangkan buku pengayaan untuk siswa SMA pada materi pertumbuhan dan perkembangan tumbuhan. Urgensi dari penelitian ini adalah bagi siswa dan guru, buku pengayaan ini berfungsi untuk mempermudah pembelajaran biologi pada materi pertumbuhan dan perkembangan tumbuhan. Bagi siswa dan guru, buku pengayaan ini menambah pilihan variasi bahan ajar dalam pembelajaran Biologi untuk materi pertumbuhan dan perkembangan tumbuhan.

Bahan ajar adalah salah satu komponen penting dalam pembelajaran. Bahan ajar yang baik akan membuat pembelajaran menjadi lebih menarik (Ramdhani \& Muhammadiyah, 2015). Kriteria bahan ajar banyak macamnya, salah satunya adalah buku pengayaan. Buku pengayaan merupakan salah satu bentuk bahan ajar yang berbentuk cetak yang memiliki spesifikasi dan tujuan untuk memberikan informasi yang lebih mendalam bagi siswa (Kustandi \& Sutjipto, 2016). Buku pengayaan sangat membantu siswa dalam melaksanakan pembelajaran. Materi yang terkandung dalam buku pengayaan haruslah berisi penelitian mutakhir beberapa tahun terakhir sehingga pengetahuan siswa menjadi lebih mendalam (Amir, Soendjoto, \& Dharmono, 2016). Hal ini diperlukan karena buku pengayaan memiliki fungsi yang berbeda dengan buku teks. Perbedaan ini salah satunya adalah berkaitan dengan materi yang terkandung dalam buku pengayaan lebih mendalam dari buku teks. Buku pengayaan juga berisi rangkuman dari materi-materi penting yang ada di buku teks (Adinugraha, 2018). Hal ini tentu sangat berbeda dengan buku teks yang berisi materi secara lengkap. Siswa yang ingin mendapatkan intisari dari suatu materi serta mendapatkan tambahan pengetahuan dapat menggunakan buku pengayaan sebagai bahan bacaannya.

Hasil belajar adalah perubahan baik itu dari pengetahuan siswa, sikap mereka, ataupun keterampilan mereka yang dihasilkan setelah proses pembelajaran berlangsung baik di dalam kelas ataupun di luar kelas. Perubahan tersebut tentunya diharapkan 
terjadi peningkatan setelah proses pembelajaran berlangsung (Ichsan \& Mulyani, 2018; Nursalam \& Efendi, 2008). Hasil belajar disebut sebagai outcome artinya adalah bahwa pembelajaran siswa yang dihasilkan setelah proses baik di kelas ataupun di luar kelas (Suprihatiningsih, 2016). Hasil belajar terdiri dari berbagai aspek. Aspek yang termasuk hasil belajar adalah kognitif, afektif, dan psikomotor. Hasil belajar kognitif menekankan pada perubahan kognitif siswa sebelum dan sesudah pembelajaran. Hasil belajar kognitif adalah hasil belajar yang diukur menggunakan instrumen penelitian berupa tes. Hasil tes yang diukur adalah berupa skor. Skor itulah yang diolah dan dilakukan analisis data. Hal yang terpenting yang dianalisis adalah bahwa basil belajar kognitif haruslah mencerminkan perubahan tingkat kognitif dari siswa tersebut (Martindar \& Hartati, 2014). Berdasarkan permasalahan rendahnya hasil belajar materi pertumbuhan dan perkembangan, kemudian bahan ajar yang digunakan masih belum memberikan informasi yang mendalam kepada siswa. Hal inilah yang mendasari perlu dikembangkan bahan ajar buku pengayaan untuk siswa.

\section{METODOLOGI PENELITIAN}

Metode penelitian yang digunakan dalam penelitian ini adalah metode research and development model pengembangan Gall \& Borg (2003). Ada 4 tahapan yang dilakukan dalam penelitian ini (1) menganalisis kebutuhan (2) merancang bahan ajar (3) melakukan pengembangan (4) melakukan validasi bahan ajar oleh ahli. Pada tahapan terakhir, ahli yang dilibatkan dalam proses validasi adalah 8 orang user yaitu merupakan Dosen Pendidikan Biologi dan guru bidang studi Biologi. Ahli memberikan penilaian dengan skala 1-4, hasil validasi kemudian dilakukan pengkategorian tingkat validitas bahan ajar tersebut sesuai yang diutarakan Ratumanan \& Laurens, (2006).

Tabel 1. Kriteria validitas Bahan Ajar

\begin{tabular}{ll}
\hline Interval Kategori & Kriteria \\
\hline $3,25>\mathrm{x} \leq 4,00$ & Sangat Valid \\
$2,50 \geq \mathrm{x} \leq 3,25$ & Valid \\
$1,75>\mathrm{x}<2,50$ & Kurang Valid \\
$1,00>\mathrm{x}<1,75$ & Tidak Valid \\
\hline
\end{tabular}




\section{HASIL PENELITIAN DAN PEMBAHASAN}

Setelah dilakukan pengembangan bahan ajar dan validasi oleh ahli, maka diperoleh skor hasil validasi. Skor tersebut kemudian diolah dan dikategorikan berdasarkan Ratumanan \& Laurens (2006) pada tabel sebelumnya. Hasil penilaian bahan ajar buku pengayaan dapat dilihat pada tabel di bawah ini.

Tabel 2. Hasil Penilaian Bahan ajar

\begin{tabular}{lcl}
\hline Expert & Skor Penilaian & Kategori \\
\hline User 1 & 3.75 & Sangat Valid \\
User 2 & 3.87 & Sangat Valid \\
User 3 & 3.83 & Sangat Valid \\
User 4 & 3.83 & Sangat Valid \\
User 5 & 3.37 & Sangat Valid \\
User 6 & 3.83 & Sangat Valid \\
User 7 & 3.29 & Sangat Valid \\
User 8 & 3.33 & Sangat Valid \\
\hline Rata-rata & 3.63 & Sangat Valid
\end{tabular}

Berdasarkan hasil yang diperoleh maka dapat disimpulkan bahwa bahan ajar tersebut layak digunakan dalam pembelajaran. Hal ini dikarenakan dari berbagai hasil penilaian, buku pengayaan tersebut memiliki kategori sangat valid. Bahan ajar yang memiliki kategori valid dianggap layak untuk digunakan dalam pembelajaran di sekolah. Secara ringkas hasil yang diperoleh dalam setiap tahapan pengembangan dapat dilihat di tabel 3.

Tabel 3. Tahapan Pengembangan beserta hasilnya

\begin{tabular}{ll}
\hline Tahapan & Hasil \\
\hline Analisis kebutuhan & Pengembangan bahan ajar pada materi \\
& pertumbuhan dan perkembangan perlu dilakukan \\
& karena termasuk materi yang sulit \\
Merancang bahan ajar & Bahan ajar dibuat dengan tujuan sebagai \\
& pengayaan bagi siswa. Terdiri dari beberapa bab \\
& dan difokuskan pada faktor internal dan faktor \\
& eksternal pertumbuhan dan perkembangan \\
& tumbuhan \\
Mengembangkan bahan ajar & Bahan ajar yang telah dikembangkan berjumlah \\
& 30 halaman. Terdiri dari 2 Bab dan evaluasi. Bab \\
& 1 bercerita tentang konsep pertumbuhan dan \\
& perkembangan pada tumbuhan. Sementara itu \\
pada bab 2 pembahasan difokuskan untuk \\
membahas faktor-faktor yang berkaitan dengan \\
pertumbuhan dan perkembangan tumbuhan seperti \\
\hline
\end{tabular}


ZPT, gen dll.

Melakukan validasi ahli Hasil validasi menunjukan bahwa bahan ajar layak digunakan. Masukan yang diterima dari para expert adalah bahwa bahan ajar yang dikembangkan lebih baik dibuat versi online juga agar lebih hemat kertas.

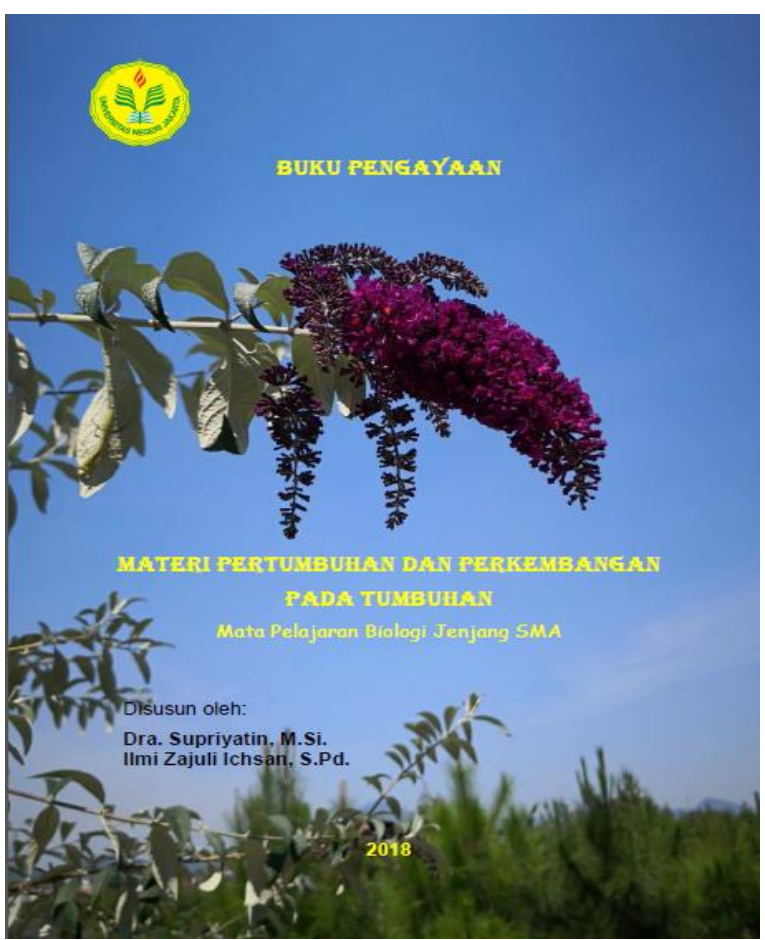

Gambar 1. Halaman sampul buku pengayaan

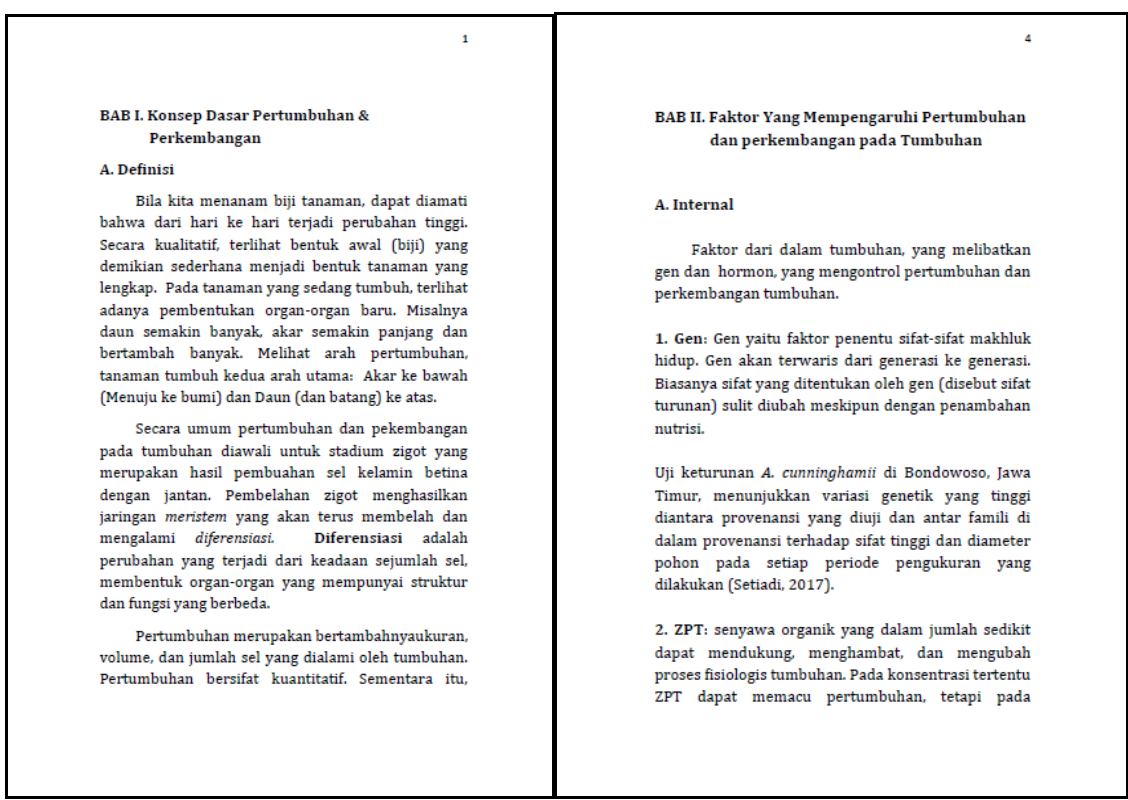

Gambar 2. Halaman isi Bab I dan Bab II buku pengayaan 
Gambar 1 dan gambar 2 diatas ini merupakan potongan gambar yang berisi buku pengayaan yang dikembangkan. Hasil pengembangan buku menunjukan keunggulan buku yaitu memiliki informasi yang lebih mendalam daripada buku teks yang biasa digunakan dalam pembelajaran di sekolah. Hal ini menjadi nilai tambah tersendiri bagi buku pengayaan yang dikembangkan ini.

Bagian buku yang dikembangkan terdiri dari bagian (1) pendahuluan (2) bagian penjelasan mengenai berbagai faktor yang mempengaruhi pertumbuhan dan perkembangan tumbuhan. Pada bagian kedua, dijabarkan faktor yang mempengaruhi yaitu faktor internal yang terdiri dari gen dan Zat Pengatur Tumbuh (ZPT). Pada bagian ini juga dijelaskan faktor eksternal yang terdiri dari suhu, kelembaban, cahaya, nutrisi, angin, gravitasi dan senyawa alelokimia. Pada bagian ini yang ditekankan adalah faktor senyawa alelokimia. Pada pengembangan buku ini lebih difokuskan pembahasannya pada ZPT dan alelokimia. Hal ini dikarenakan pemahaman siswa mengenai ZPT masih sering keliru dan perlu ditambah. Pada materi ZPT terdiri dari auksin, giberelin, sitokinin, asam absisat, etilen dan ZPT sintetis. Pada bagian materi di buku ini, pembahasan ZPT diberikan tidak hanya materi yang lebih mendalam melainkan juga diberikan contoh kasus dari masing-masing ZPT. Contoh-contoh kasus tersebut diambil dari berbagai hasil penelitian yang sudah dilakukan oleh berbagai peneliti. Tidak hanya hasil penelitian saja, tetapi harus relevan dengan kehidupan sehari-hari. Selain itu, pada materi alelokimia dibuat lebih mendalam agar siswa lebih memahami berbagai kasus yang ada. Alasan lain adalah agar lebih aplikatif, mengingat bahwa alelokimia bisa dikembangkan menjadi bioherbisida alami. Dipaparkannya hal ini diharapkan menjadi inovasi baru dalam pengembangan buku pengayaan sehingga siswa juga menjadi lebih inovatif (Ahokoski, Korventausta, Veermans, \& Jaakkola, 2017; Ito \& Kawazoe, 2015).

Pengembangan buku pengayaan sebenarnya dapat dilakukan di berbagai materi dalam pembelajaran Biologi. Materi pertumbuhan dan perkembangan tumbuhan merupakan salah satu materi yang dapat dilakukan penambahan materi menggunakan buku pengayaan ini. Buku pengayaan ini dapat membantu siswa untuk berfikir lebih kritis, merangsang daya analisis siswa, sehingga dapat merangsang peningkatan hasil belajar dan Higher Order Thinking Skills siswa tersebut. Hal ini dikarenakan buku pengayaan ini mengandung berbagai materi yang berasal dari hasil penelitian. Selain hasil penelitian, buku pengayaan juga mengandung berbagai teori yang lebih mendalam. 
Materi yang seperti ini dapat meningkatkan kemampuan abad 21 karena berbasis dari masalah dan penelitian (Camacho \& Legare, 2015; Lee, 2014; Song, 2016; Tanujaya, Mumu, \& Margono, 2017; Wall, 2015). Materi yang berbasis hasil penelitian biasanya akan membuat siswa menjadi lebih tertarik karena relevan dengan kehidupan seharihari. Siswa bisa mengaplikasikan konsep-konsep dari hasil penelitian yang terkini untuk diaplikasikan pada kehidupan. Hal ini akan merangsang daya analisis siswa dan kritis siswa yang berakibat pada peningkatan kemampuan berpikir tingkat tinggi (Wall, 2015).

Buku pengayaan pertumbuhan dan perkembangan tumbuhan ini juga memiliki kelebihan dimana mudah untuk dibawa kemana-mana dikarenakan bisa dimasukan dalam bentuk softcopy dan dapat pula dalam bentuk cetak. Selain itu, buku pengayaan ini memiliki pembahasan yang mudah dipahami oleh siswa dikarenakan penggunaan bahasa dalam buku tersebut sudah disesuaikan untuk siswa. Penggunaan bahasa juga diarahkan agar merangsang daya analisis siswa dan merangsang siswa agar bisa lebih kritis. Data-data yang berasal dari hasil penelitian yang ditampilkan dalam buku ini akan merangsang kemampuan berfikir siswa, karena siswa akan belajar untuk menganalisis permasalahan (Boholano, 2017; Ichsan, Iriani, \& Hermawati, 2018; Khoiriyah \& Husamah, 2018; Song, 2016; Taft, 2015).

Adapun kekurangan dari buku ini adalah masih minimnya gambar yang digunakan untuk menjelaskan berbagai pembahasan yang digunakan pada buku tersebut. Selain gambar juga kurangnya jumlah hasil penelitian yang dirujuk sebagai pembahasan. Memang, idealnya harusnya lebih dari 50 artikel yang digunakan dalam merujuk pembahasan tersebut. Semakin banyak rujukan bisa menampilkan informasi yang lebih banyak kepada siswa. Selain itu, sebenarnya buku ini juga bisa dikembangkan dalam bentuk yang lain dalam hal ini dimasukkan kedalam bentuk lain yang berbasis digital contohnya saja website, dikarenakan pembelajaran di era modern sekarang ini sudah bisa dikembangkan bahan ajar buku digital (Ballatore \& Natale, 2016; Grover, 2016; Hsiao, Tiao, \& Chen, 2016; Nugraini, Choo, Hin, \& Hoon, 2013; Reyna, Hanham, \& Meier, 2018).

Pengembangan materi pengayaan materi pertumbuhan dan perkembangan juga bisa dilakukan dengan bentuk yang lain misalnya menggunakan media sosial. Pembelajaran yang dibatasi oleh waktu sepertinya agak sulit jika hanya menggunakan buku pengayaan yang berbentuk cetak. Apabila ditinjau dari jumlah pertemuan yang 
terbatas, sementara siswa diharuskan memahami berbagai konsep dalam materi tersebut. Guru bisa melakukan siasat dengan cara menggunakan media yang tidak terbatas dengan waktu, selain itu juga yang bisa diaplikasikan dengan mudah oleh siswa. Hal ini bisa dilakukan sebuah inovasi dengan menggunakan media sosial misalnya. Penggunaan media sosial dalam pembelajaran memungkinkan siswa dapat mengakses materi pembelajaran itu dimana saja dan kapan saja sehingga tidak lagi terbatas oleh ruang dan waktu (Alsadoon, 2018; Czerkawski, 2014; Lakonpol, Ruangsuwan, \& Terdtoon, 2015).

Ketika siswa sudah bisa memahami materi pertumbuhan dan perkembangan dengan baik, maka akan berdampak kepada pembelajarannya. Hal ini sesuai dengan tuntutan kemampuan siswa pada abad 21 dimana siswa tidak hanya bisa memahami konten tetapi juga diharuskan bisa menganalisis berbagai permasalahan yang ada di dalam kehidupannya sehari-hari. Misalnya saja dalam hal ini bioherbisida. Setelah siswa membaca materi pengayaan dari buku ini tentang manfaat senyawa alelokimia untuk menghambat pertumbuhan gulma, maka mereka bisa melakukan inovasi sendiri dengan membuat ekstrak yang berdampak pada terhambatnya pertumbuhan gulma di area sekitar rumahnya. Hal ini tentu akan berdampak terhadap pengurangan jumlah gulma secara alami tanpa merusak lingkungan. Selain itu, siswa juga akan bisa mengaplikasikan berbagai hasil penelitian yang dipaparkan dalam buku ini mengenai ZPT. Siswa akan bisa melihat faktor ZPT terhadap pertumbuhan dan perkembangan tumbuhan di sekitar rumahnya. Hal ini membuat mereka akan menganalisis cara yang bisa dilakukan untuk membuat pohon di rumah mereka lebih cepat pertumbuhannya. Harapannya dari dikembangkannya buku ini adalah terciptanya daya analisis siswa yang tinggi, hal itu dikarenakan siswa yang kritis dan menjadi aktif dalam pembelajaran akan membuat mereka bisa menemukan hal yang baru dan mampu memberikan inovasi untuk masa yang akan datang (Stover \& Ziswiler, 2017; Tesfaye \& Berhanu, 2015)

\section{SIMPULAN}

Berdasarkan hasil penelitian, dapat disimpulkan bahwa buku pengayaan materi pertumbuhan dan perkembangan tumbuhan layak digunakan untuk siswa. Hal ini dikarenakan perlunya sebuah tambahan materi, selain yang sudah diajarkan oleh guru. Penambahan materi pengayaan melalui bahan ajar buku pengayaan ini akan memperluas pengetahuan siswa dalam mempelajari berbagai konsep berkaitan dengan pertumbuhan dan perkembangan tumbuhan. Pemilihan ukuran buku seharusnya bisa lebih variatif. 
Pemilihan referensi yang digunakan bisa disesuaikan pembahasannya agar lebih mudah dipahami. Sebaiknya untuk peneliti yang lain, bisa mengembangkan buku ini ke dalam bentuk digital.

\section{DAFTAR PUSTAKA}

Adinugraha, F. (2018). Gambaran Persepsi Peserta Didik tentang Kebermanfaatan Buku Pengayaan Ujian Nasional Biologi. Jurnal EduMatSains, 2(2), 99-114.

Ahokoski, E., Korventausta, M., Veermans, K., \& Jaakkola, T. (2017). Teachers' Experiences of an Inquiry Learning Training Course in Finland. Science Education International, 28(4), 305-314.

Alsadoon, E. (2018). Motivating Factors for Faculty to Use Web Applications in Education. TOJET: The Turkish Online Journal of Educational Technology, 17(3), 73-90.

Amir, A., Soendjoto, M. A., \& Dharmono, D. (2016). Validity of Enriched TeachingMaterials For SMP / MTs Based on the Research of Eating Behavior of LongTail Macaque (Macaca Fascicularis, Raffles) in the Rubber Forest. Proceeding Biology Education Conference, 13(1), 58-62.

Ballatore, A., \& Natale, S. (2016). E-readers and the death of the book: Or, new media and the myth of the disappearing medium. New Media and Society, 18(10), 2379-2394. https://doi.org/10.1177/1461444815586984

Black, J. D., Bauer, K. N., Spano, G. E., Voelkel, S. A., \& Palombaro, K. M. (2017). Grand Rounds: A Method for Improving Student Learning and Client Care Continuity in a Student- Run Physical Therapy Pro Bono Clinic. Journal of the Scholarship of Teaching and Learning, 17(3), 68-88. https://doi.org/10.14434/josotl.v17i3.21158

Boholano, H. B. (2017). Smart Social Networking: 21st Century Teaching And Learning Skills. Research in Pedagogy, 7(1), 21-29. https://doi.org/10.17810/2015.45

Camacho, D. J., \& Legare, J. M. (2015). Opportunities to Create Active Learning Techniques in the Classroom. Journal of Instructional Research, 4, 38-45.

Czerkawski, B. Ö. (2014). The Semantic Web in Education. TOJET: The Turkish Online Journal of Educational Technology, 13(4), 144-147. Retrieved from http://er.educause.edu/ /media/files/article-downloads/eqm0840.pdf

Gall, M. D., Gall, J. P., \& Borg, W. R. (2003). Educational Research An Introduction. San Fransisco: Pearson Education.

Grover, A. P. (2016). E-Books as Non-interactive Textual Compositions : An Argument for Simplicity over Complexity in Future E-Book Formats. Publishing Research Quarterly, 32(3), 178-186. https://doi.org/10.1007/s12109-016-9470-7

Hsiao, C.-C., Tiao, M.-M., \& Chen, C.-C. (2016). Using interactive multimedia e-Books for learning blood cell morphology in pediatric hematology. BMC Medical Education, 16(1), 290. https://doi.org/10.1186/s12909-016-0816-9 
Ichsan, I. Z., Dewi, A. K., Hermawati, F. M., \& Iriani, E. (2018). Pembelajaran IPA dan Lingkungan: Analisis Kebutuhan Media Pembelajaran pada SD, SMP, SMA di Tambun Selatan, Bekasi. JIPVA (Jurnal Pendidikan IPA Veteran), 2(2), 131140. https://doi.org/10.31331/jipva.v2i2.682

Ichsan, I. Z., Iriani, E., \& Hermawati, F. M. (2018). Peningkatkan Keterampilan Berpikir Tingkat Tinggi (Higher Order Thinking Skills) Pada Siswa Sekolah Dasar Melalui Video Berbasis Kasus Pencemaran Lingkungan. Edubiotik: Jurnal Pendidikan, Biologi Dan Terapan, 3(02), 12-18.

Ichsan, I. Z., \& Mulyani, S. W. W. (2018). Improving Students' Motoric Skills Through Demonstration Method in Recycling Plastic Waste. JPBI (Jurnal Pendidikan Biologi Indonesia), 4(2), 189-194. https://doi.org/10.22219/jpbi.v4i2.5890

Ichsan, I. Z., Sigit, D. V., \& Miarsyah, M. (2018). Learning Environment: Gender Profile of Students' Pro-Environmental Behavior (PEB) based on Green Consumerism. Tadris: Jurnal Keguruan dan Ilmu Tarbiyah, 3(2), 97-107. https://doi.org/10.24042/tadris.v3i2.3358

Ito, H., \& Kawazoe, N. (2015). Active Learning for Creating Innovators: Employability Skills beyond Industrial Needs. International Journal of Higher Education, 4(2), 81-91. https://doi.org/10.5430/ijhe.v4n2p81

Khoiriyah, A. J., \& Husamah, H. (2018). Problem-based learning: Creative thinking skills, problem-solving skills, and learning outcome of seventh grade students. JPBI (Jurnal Pendidikan Biologi Indonesia), 4(2), 151-160. https://doi.org/10.22219/jpbi.v4i2.5804

Kustandi, C., \& Sutjipto, B. (2016). Media Pembelajaran Manual dan Digital. Bogor: Ghalia Indonesia.

Lakonpol, T., Ruangsuwan, C., \& Terdtoon, P. (2015). Development of web-based learning environment model to enhance cognitive skills for undergraduate students in the field of electrical engineering. Educational Research and Reviews, 10(21), 2806-2813. https://doi.org/10.5897/ERR2015.2470

Lee, S. M. (2014). The relationships between higher order thinking skills, cognitive density, and social presence in online learning. Internet and Higher Education, 21, 41-52. https://doi.org/10.1016/j.iheduc.2013.12.002

Martindar, F. B., \& Hartati, S. C. Y. (2014). Pengaruh Model Pembelajaran Kooperatif Tipe Team Games Tournament ( TGT ) Terhadap Hasil Belajar Renang Gaya Bebas. Jurnal Pendidikan Olahraga Dan Kesehatan, 2(1), 164-170.

Nugraini, S. H., Choo, K. A., Hin, H. S., \& Hoon, T. S. (2013). Students' Feedback of e-AV Biology Website and the Learning Impact towards Biology. Procedia Social and Behavioral Sciences, 103, 860-869. https://doi.org/10.1016/j.sbspro.2013.10.408

Nursalam, \& Efendi, F. (2008). Pendidikan dalam Keperawatan. Jakarta: Salemba Medika.

Ramdhani, M. A., \& Muhammadiyah, H. (2015). The Criteria of Learning Media Selection for Character Education in Higher Education. In International Conference of Islamic Educatios in Shoutheast Asia (pp. 1-9).

Ratumanan, T. ., \& Laurens, T. (2006). Evaluasi Hasil Belajar yang Relevan dengan Kurikulum Berbasis Kompetensi. Surabaya: Unesa University Press. 
Reyna, J., Hanham, J., \& Meier, P. (2018). The Internet explosion, digital media principles and implications to communicate effectively in the digital space. $E$ Learning and Digital Media, 15(1), 36-52. https://doi.org/10.1177/2042753018754361

Seechaliao, T. (2017). Instructional Strategies to Support Creativity and Innovation in Education. Journal of Education and Learning, 6(4), 201-208. https://doi.org/10.5539/jel.v6n4p201

Song, X. (2016). "Critical Thinking" and Pedagogical Implications for Higher Education. East Asia, 33(1), 25-40. https://doi.org/10.1007/s12140-015-9250-6

Srisumra, J., Nontamolee, W., \& Srijamon, S. (2014). Cooperative Learning Activities in Arts of Prathom Suksa 4 Students Khon Kaen University Demonstration School Primary Section (Modindaeng). Procedia - Social and Behavioral Sciences, 112(Iceepsy 2013), 677-682. https://doi.org/10.1016/j.sbspro.2014.01.1217

Stover, S., \& Ziswiler, K. (2017). Impact of Active Learning Environments on Community of Inquiry. International Journal of Teaching and Learning in Higher Education, 29(3), 458-470. Retrieved from http://ezproxy.lib.uconn.edu/login?url=https://search.ebscohost.com/login.aspx? direct $=$ true $\& \mathrm{db}=$ eric $\& \mathrm{AN}=\mathrm{EJ} 1150760 \&$ site $=$ ehost-live

Suprihatiningsih. (2016). Perspektif Manajemen Pembelajaran Program Keterampilan. Yogyakarta: Deepublish.

Taft, M. M. (2015). Higher - Order Critical Thinking in Teacher Preparation. In Transformative Researchers and Educators for Democracy (pp. 57-73).

Tanujaya, B., Mumu, J., \& Margono, G. (2017). The Relationship between Higher Order Thinking Skills and Academic Performance of Student in Mathematics Instruction. International Education Studies, 10(11), 78-85. https://doi.org/10.5539/ies.v10n11p78

Tesfaye, S., \& Berhanu, K. (2015). Improving Students 'Participation in Active Learning Methods: Group Discussions, Presentations And Demonstrations : A Case of Madda Walabu University Second Year Tourism Management Students of 2014. Journal of Education and Practice, 6(22), 29-33.

Uzun, N. (2012). A Sample of Active Learning Application in Science Education: The Thema "Cell" with Educational Games. Procedia - Social and Behavioral Sciences, 46, 2932-2936. https://doi.org/10.1016/j.sbspro.2012.05.592

van der Veen, C., \& van Oers, B. (2017). Advances in research on classroom dialogue: learning outcomes and assessments. Learning and Instruction, 48, 1-4. https://doi.org/10.1016/j.learninstruc.2017.04.002

Wall, T. F. (2015). The Transferability of Higher Order Cognitive Skills. Procedia Social and Behavioral Sciences, 174, 233-238. https://doi.org/10.1016/j.sbspro.2015.01.652 